\title{
Young Striped Searobins (Triglidae: Prionotus evolans) in the Hudson River
}

\author{
Robert E. Schmidt \\ Bard College at Simon's Rock, 84 Alford Rd., \\ Great Barrington, MA 01230, USA \\ Email: schmidt@simons-rock.edu
}

Schmidt, R. E. 2007. Young striped searobins (Triglidae: Prionotus evolans) in the Hudson River. J. Northw. Atl. Fish. Sci., 38: 67-71. doi: 10.2960/J.v38.m608

\begin{abstract}
The spatial and temporal distribution of young of year searobin (Prionotus) was delineated in the Hudson River from museum specimens. All young searobins in the Hudson River were Prionotus evolans (L.). The smallest young striped searobin are found in the southern estuary in July and they move farther upriver as they grow. Most individuals leave the estuary in the autumn, but some latespawned individuals probably remain in the estuary through the winter and into late spring.
\end{abstract}

Key words: Distribution, estuary, Hudson River, juveniles, Prionotus evolans

\section{Introduction}

There are two species of searobin (Triglidae) found in abundance in New York waters (Briggs and Waldman, 2002); the striped searobin (Prionotus evolans (L.) and the northern searobin (P. carolinus (L.). Although adults are well described and both species are known from the Hudson River (Smith, 1985), early life stages have been difficult to identify. Able and Fahay (1998) provided clear means of identifying early life stages of these two species. The purpose of this paper is to summarize the occurrences of young Prionotus in the Hudson River estuary to document how searobin early life stages use the estuary.

\section{Material and Methods}

The Hudson River is one of the largest estuaries in the northeastern United States with tidal influence extending 150 miles inland from its mouth. Geyer and Chant (2006) provided a recent summary of the character of the estuary. Miles up the river (RM) is an approximate designation of the sampling location in the Hudson River (Fig. 1) with $\mathrm{RM}=0$ being the southern tip of Manhattan (The Battery) and $\mathrm{RM}=153$ being the Federal Dam at Troy, the upstream limit of tidal influence. The specimens examined in this study (Table 1) were collected in a multiyear, estuary-wide ichthyoplankton survey that has been done annually since 1973 and are catalogued at the New York State Museum (NYSM). Between 150-210 sites from RM 0-150 (Fig. 1) were sampled weekly from April to October with epibenthic sleds and Tucker trawls. Klauda et al. (1988) summarized the methodology of this survey which has continued with only minor alterations since their paper.
For each specimen, the following standard measurements were taken with a digital caliper: Standard length (SL), head length, pectoral fin length, and preanal length. I also measured the length of the pectoral fin that extended past the anal-fin origin by appressing the fin against the fish's body and measuring the part of the fin extending posterior to a vertical line from the anal-fin origin with a digital caliper. Fin-element counts were done on the first and second dorsal, anal, pectoral, and pelvic fins under a stereomicroscope.

\section{Results}

A total of 43 Prionotus from the Hudson River were examined of 12.8-64.1 mm SL. All specimens were P. evolans following Able and Fahay (1998). The smallest $P$. carolinus in the NYSM collection from the Hudson River was $122 \mathrm{~mm}$ SL (NYSM 14346, RM = 42); clearly not a young individual. The NYSM specimens are well past the larval stage (by the criterion of having adult fin element counts) and would be classified as benthic (settled) individuals (McBride et al., 2002). All specimens (where gear was listed) were collected with an epibenthic sled, which samples near-bottom habitat. None was collected in the pelagic Tucker trawl and one (NYSM 2573) was impinged on the intake screens at the Indian Point nuclear plant $(\mathrm{RM}=42)$. These observations all suggest that the specimens were in the settled stage of development. Developmental stages of striped searobin have been described (Fahay, 1983; Yuschak, 1985), but settled juveniles are not collected in plankton gear and illustrations are less common (Fahay, 2007). New illustrations of development of settled juveniles are provided here (Fig. 2). 


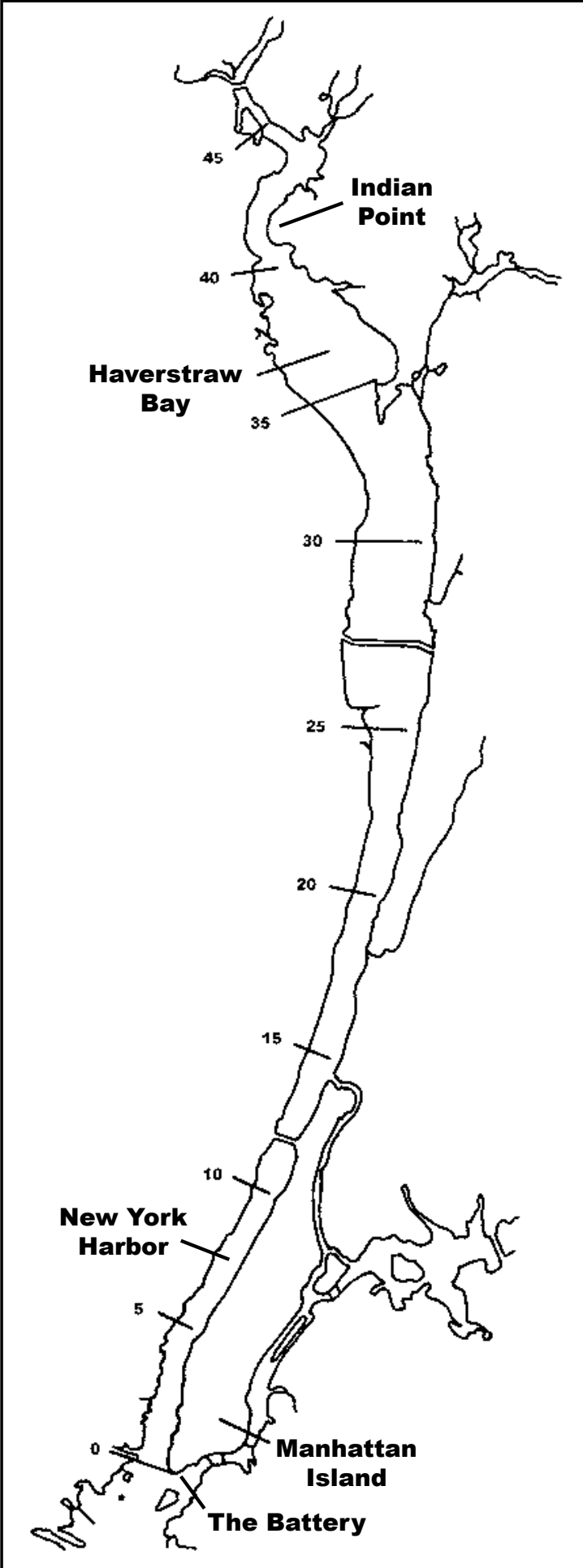

Fig. 1. Map of the southernmost 40 miles of the Hudson River, New York and New Jersey (from the Bear Mountain Bridge to the southern tip of Manhattan). The numbered horizontal lines indicate approximate locations of miles up river $(\mathrm{RM})$ where $\mathrm{RM}=0$ is the southern tip of Manhattan.
TABLE 1. Specimens of young striped searobin (Prionotus evolans) in the fish collection of the New York State Museum (NYSM) from the Hudson River estuary.

\begin{tabular}{|c|c|c|c|c|}
\hline $\begin{array}{c}\text { NYSM } \\
\text { Catalogue } \\
\text { No. }\end{array}$ & $\begin{array}{l}\text { Miles } \\
\text { up } \\
\text { river }\end{array}$ & Date & $\begin{array}{c}\text { No. of } \\
\text { Specimens }\end{array}$ & $\begin{array}{c}\text { Standard } \\
\text { Length } \\
(\mathrm{mm})\end{array}$ \\
\hline 2573 & 2 & 7 Oct 1976 & 1 & 56.9 \\
\hline 12099 & 15 & 8 Aug 1975 & 1 & 18.2 \\
\hline 14264 & 14 & 17 Aug 1978 & 8 & $15.5-24.9$ \\
\hline 14271 & 13 & 17 Aug 1978 & 3 & $18.1-29.5$ \\
\hline 14290 & 24 & 6 Sep 1978 & 1 & 57.5 \\
\hline 14307 & 42 & 13 Oct 1977 & 1 & 59.8 \\
\hline 14309 & - & 14 Sep 1976 & 1 & 55.6 \\
\hline 14365 & 42 & 14 Sep 1978 & 1 & 64.1 \\
\hline 14435 & - & 22 Aug 1978 & 1 & 26.3 \\
\hline 14436 & 42 & 7 Sep 1978 & 1 & 31.2 \\
\hline 14437 & 21 & 22 Aug 1978 & 1 & 23.2 \\
\hline 14438 & 16 & 31 Aug 1976 & 1 & 12.8 \\
\hline 14439 & 14 & 17 Aug 1978 & 5 & $16.9-25.8$ \\
\hline 46328 & 14 & 9 Jul 1988 & 1 & 16.4 \\
\hline 47157 & 17 & 25 Aug 1988 & 1 & 19.0 \\
\hline 47222 & 15 & 25 Jun 1988 & 1 & 27.8 \\
\hline 47230 & 2 & 24 Jun 1988 & 2 & $16.6-21.9$ \\
\hline 52510 & 26 & 7 Sep 1988 & 1 & 28.3 \\
\hline 54677 & 13 & 8 Aug 1988 & 1 & 14.9 \\
\hline 58397 & 15 & 6 Sep 1988 & 3 & $35.8-42.8$ \\
\hline 58417 & 18 & 6 Sep 1988 & 1 & 48.6 \\
\hline 58476 & 13 & 8 Aug 1988 & 2 & $13.6-33.5$ \\
\hline 60048 & 11 & 8 Aug 1988 & 3 & $13.1-15.5$ \\
\hline
\end{tabular}

Mophometrics were relatively constant for all specimens examined (Table 2), except that the overlap of the pectoral fin past the anus was very small (particularly in very small specimens) and varied considerably although the pectoral fin always extended beyond the anus, characteristic of $P$. evolans (Able and Fahay, 1998). Fin-element counts also showed substantial variation with the pelvic-fin elements being the most consistent. Fin-element counts, although listed as definitive (Able and Fahay, 1998), are too variable to distinguish all specimens from the Hudson River.

The smallest (youngest) striped searobin are seen in late July-early August (Fig. 3) in New York Harbor (Manhattan). Although my data are from specimens collected over several years, there appears to be an upstream movement from New York Harbor into Haverstraw Bay (Figs. 1 and 3) as the seasons progress. The growth rate was approximately $0.6 \mathrm{~mm} /$ day (from $\sim 15 \mathrm{~mm}$ to $\sim 65 \mathrm{~mm}$ ) between late July and mid-October (Fig. 3) and is close to that reported by McBride et al. (2002).

Ichthyoplankton surveys in the Hudson Estuary usually ended in October (Klauda et al., 1988), but lack of large individuals in spring collections indicate that striped 


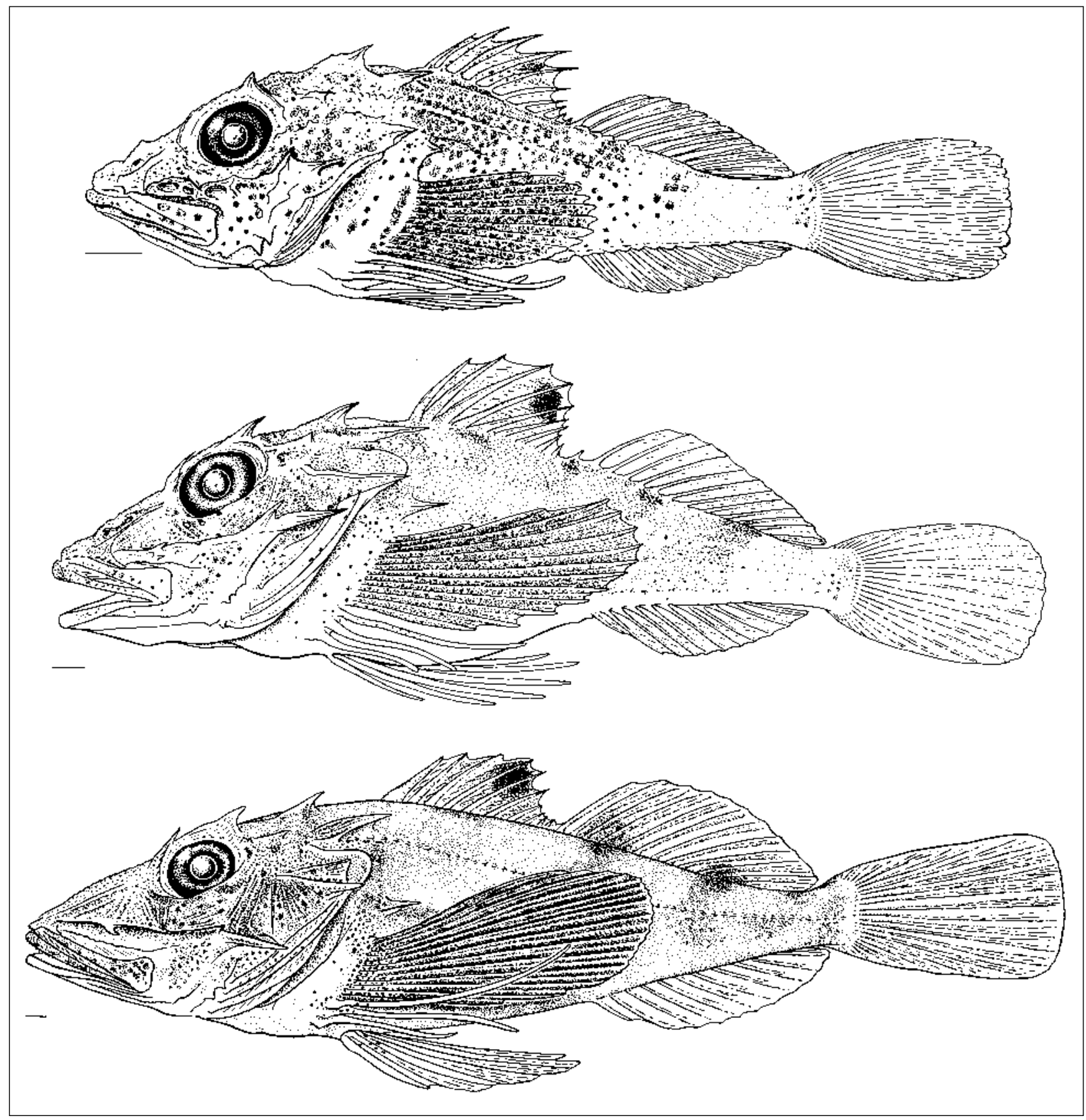

Fig.2. Illustrations of young Hudson River striped searobin (Prionotus evolans). The horizontal scale bars (located under the tip of the lower jaw) equal 1 millimeter. Top specimen is NYSM 14438 (12.8 mm SL), middle specimen is NYSM 14437 (23.2 mm SL), and bottom specimen is NYSM 58397 (40.0 mm SL).

searobin leave the estuary in late autumn or early winter. The larger fish collected in June (Fig. 3) could be from a cohort spawned in May (Wilk et al., 1990) or, more likely, are late spawned individuals (20 $\mathrm{mm} \mathrm{SL}$ in autumn) that grew little over winter (Able and Fahay, 1998). I cannot age the specimens because they were fixed in formalin, so I cannot distinguish between these two scenarios.

\section{Discussion}

Able and Fahay (1998) listed juveniles of P. evolans, and eggs, larvae, and juveniles of $P$. carolinus, from the Raritan-Hudson system (including Sandy Hook Bay). However, Dovel (1981) surveyed the lower Hudson River in 1972 with towed conventional plankton nets 
and recorded no searobin at all. Reproduction of both species occurs on the inner Continental Shelf (McBride and Able, 1994) and settlement often occurs well offshore. In P. carolinus, young do not seem to enter estuaries until they are almost a year old in the spring (Able and Fahay, 1998). Striped searobin spawn closer to shore and early juveniles are more likely to enter estuaries than northern searobin (Able and Fahay, 1998). My observation that all the small searobin in the lower Hudson estuary are $P$. evolans is similar to the above observations and the reports of eggs and larvae of northern searobin are not from the Hudson Estuary but are primarily from Sandy Hook Bay and further offshore.

The smallest striped searobin $(<15 \mathrm{~mm} \mathrm{SL})$ in the Hudson River were seen in early August (Fig. 3). The smallest individuals would be about one month old (based on growth of $0.6 \mathrm{~mm} /$ day, McBride et al., 2002) which would indicate spawning in early July for this cohort, similar to literature reports (Able and Fahay, 1998; Wilk et al., 1990). By early October, most of the young searobin have left the estuary leaving a small number of fairly large individuals $60-65 \mathrm{~mm} \mathrm{SL}$. This pattern of small striped searobin entering the Hudson River soon after settlement and then most leaving by late autumn has been seen in other estuaries (Able and Fahay, 1998).

There is an anomalous occurrence of $15-30 \mathrm{~mm} \mathrm{SL}$ individuals in the lower Hudson Estuary in early June (Table 2; Fig. 3 - front right corner). These individuals are larger than the cohort seen in early August and would

TABLE 2. Mean and range of morphometric and meristic observations on settled striped searobin (Prionotus evolans) juveniles from the Hudson River estuary.

\begin{tabular}{|c|c|c|}
\hline Observation & Mean & Range \\
\hline Standard length (mm) & 26.8 & $12.8-64.1$ \\
\hline Standard length/Head length & 2.2 & $1.9-2.4$ \\
\hline Standard length/Preanal length & 1.5 & $1.4-1.7$ \\
\hline Head length/Pectoral fin length & 1.4 & $1.0-1.8$ \\
\hline Pectoral fin length past anus (mm) & 2.5 & $0.3-8.5$ \\
\hline Dorsal spine count & 9.7 & $8-11$ \\
\hline Dorsal ray count & 11.4 & $8-13$ \\
\hline Anal ray count & 10.5 & $7-12$ \\
\hline Pectoral ray count ${ }^{1}$ & 11.7 & $10-13$ \\
\hline Pelvic spine plus ray count & 5.9 & $5-7$ \\
\hline
\end{tabular}

${ }^{1}$ Excluding the three finger-like ventral rays. have been spawned in early April to May, much earlier than spawning has been reported for this species (Able and Fahay, 1998). These early season searobin are probably late spawned individuals that grew little over the winter (Able and Fahay, 1998) which means that the Hudson River has two small age-classes present which has not been reported elsewhere. Determining age from otoliths (McEachran and Davis, 1970) in small early season searobin may resolve this question however the NYSM specimens were fixed in formalin and therefore otolith aging is probably not possible.

The Hudson River estuary has 211 documented fish species (Waldman et al., 2006). Some fishes are full-time residents, like mummichog (Fundulus heteroclitus), whereas others, like scrawled cowfish (Acanthostracion quadricornis), are very occasional visitors (Schmidt and Lake, 2001). My data suggest that striped searobin is a seasonal resident, much like bluefish (Pomatomus saltatrix), in that spawning occurs in continental marine waters (Kendall and Walford, 1979) and small juveniles enter the Hudson River in summer and stay through the autumn (McBride and Conover, 1991).

\section{Acknowledgements}

I thank Bob Daniels, Rick Morse, and Bryan Weatherwax for providing access and for their help with NYSM specimens. Bob Daniels also read an early draft of this paper. Kathleen Schmidt drew the figures. Generous financial support came from F. Peter Rose.

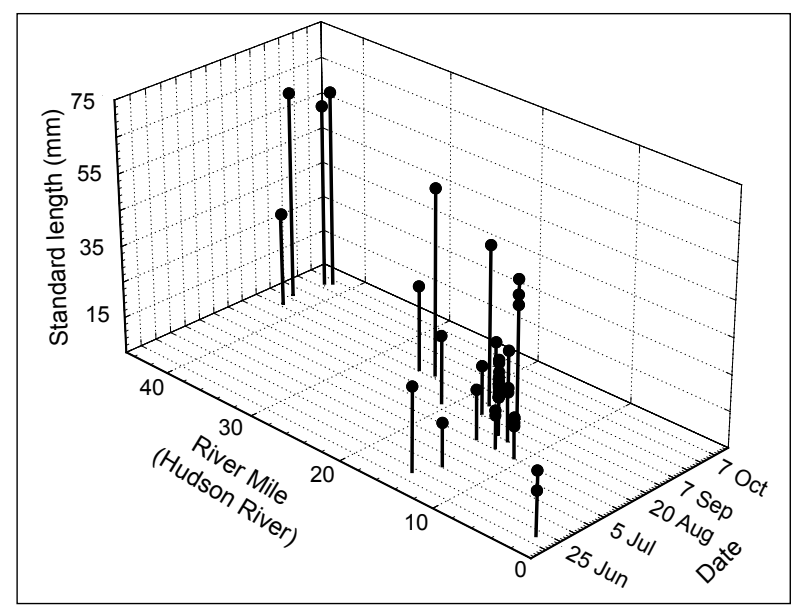

Fig. 3. Graph of the distribution of young striped searobin (Prionotus evolans) in time and space by size in the Hudson River. Larger individuals are caught later in the season and generally further upriver. 


\section{References}

ABLE, K. W., and M. P. FAHAY. 1998. The first year in the life of estuarine fishes in the Middle Atlantic Bight. Rutgers University Press. New Brunswick, New Jersey, $342 \mathrm{p}$.

BRIGGS, P. T., and J. R. WALDMAN. 2002. Annotated list of fishes reported from the marine waters of New York. Northeast. Nat., 9: 47-80.

DOVEL, W. L. 1981. Ichthyoplankton of the lower Hudson River estuary, New York. NY Fish Game J., 28: 21-39.

FAHAY, M. P. 1983. Guide to the early stages of marine fishes occurring in the western North Atlantic Ocean, Cape Hatteras to the southern Scotian Shelf. J. Northw. Atl. Fish. Sci., 4: 1-423.

FAHAY, M. P. 2007. Early Stages of Fishes in the Western North Atlantic Ocean (Davis Strait, Southern Greenland and Flemish Cap to Cape Hatteras) Volume 2. Northwestern Atlantic Fisheries Organization, Dartmouth, Nova Scotia, 765 p.

GEYER, W. R., and R. CHANT. 2006. The physical oceanography processes in the Hudson River Estuary. In: The Hudson River Estuary. J. S. Levinton and J. R. Waldman (eds.). Cambridge University Press, New York, p. 24-38.

KENDALL, A. W., Jr., and L. W. WALFORD. 1979. Sources and distribution of bluefish, Pomatomus saltatrix, larvae and juveniles on the east coast of the United States. Fish. Bull., 77: 213-228.

KLAUDA, R. J., P. H. MUESSIG, and J. A. MATOUSEK. 1988. Fisheries data sets compiled by Utility-sponsered research in the Hudson River Estuary. In: Fisheries Research in the Hudson River. C. L. Smith (ed.). SUNY Press. New York, p. 7-88.

McBRIDE, R. S., and K. W. ABLE. 1994. Reproductive seasonality, distribution, and abundance of Prionotus carolinus and P. evolans (Pisces: Triglidae) in the New York Bight. Estuar. Coast. Shelf Sci., 38: 173-188. doi:10.1006/ecss.1994.1011

McBRIDE, R. S., and D. O. CONOVER. 1991. Recruitment of young-of-the-year bluefish (Pomatomus saltatrix) to the New York Bight: Variation in abundance and growth of spring- and summer-spawned cohorts. Mar. Ecol. Prog. Ser., 78: 205-216. doi:10.3354/ meps078205

McBRIDE, R. S., M. P. FAHAY, and K. W. ABLE. 2002. Larval and settlement periods of the northern searobin (Prionotus carolinus) and the striped searobin (P. evolans). Fish. Bull., 100: 63-73.

McEACHRAN, J. D., and J. DAVIS. 1970. Age and growth of the striped searobin. Trans. Am. Fish. Soc., 99: 343-352. doi:10.1577/1548-8659(1970)99<343: AAGOTS $>2.0 . \mathrm{CO} ; 2$

SCHMIDT, R. E. and T. R. LAKE. 2001. A benthic juvenile scrawled cowfish (Acanthostracion quadricornis) from the lower Hudson River estuary. Northeast. Nat., 8: 343-346.

SMITH, C. L. 1985. The inland fishes of New York State. New York State Department of Environmental Conservation, Albany, New York, 522 p.

WALDMAN, J. R., T. R. LAKE, and R. E. SCHMIDT. 2006. Biodiversity and zoogeography of the fishes of the Hudson River watershed and estuary. In: Hudson River Fishes and Their Environment, . J. R. Waldman, K. E. Limburg, and D. Strayer (eds.). Symp. Am. Fish. Soc., 51: 129-150.

WILK, S. J., W. W. MORSE, and L. L. STEHLIK. 1990. Annual cycles of gonad-somatic indices as indicators of spawning activity for selected species of finfish collected from the New York Bight. Fish. Bull., 88: 775-786.

YUSCHAK, P. 1985. Fecundity, eggs, larvae and osteological development of the striped sea robin (Prionotus evolans) (Pisces, Triglidae). J. Northw. Att. Fish. Sci., 6: 65-85. 